\title{
Anti-osteoporotic activities of the collagen extracted from Carapacis et Plastri Testudinis on a ROS1728 cell line in vitro.
}

\author{
Dalin Wang ${ }^{1}$, Zhenyu Wu ${ }^{1}$, Weihai Jiang ${ }^{1}$, Mingcheng Li ${ }^{2 \# *}$, Siqi Duan², Jiayu Chen ${ }^{3 \#}$ \\ ${ }^{1}$ Department of Surgery, Associated Hospital, Beihua University, Jilin, Jilin, PR China \\ ${ }^{2}$ Department of Clinical Diagnosis, School of Laboratory Medicine, Beihua University, Jilin, Jilin, PR China \\ ${ }^{3}$ Department of Clinical Laboratory, Shaoxing University, Shaoxing, Zhejing, PR China \\ \#These authors contributed equally to this work
}

\begin{abstract}
Purpose: The decoction of collagen extracted from Carapacis et Plastri Testudinis (CCPT) has been reported to have an effect of anti-osteoporosis. The present study was to investigate the in vitro molecular mechanisms effect of CCPT on ROS1728 differentiation and proliferation.

Methods: Rat osteoblast cell line (ROS 1728) was cultured and exposed to CCPT at different concentrations. The effect of CCPT on the proliferation of ROS1728 was evaluated through detecting the activity of Alkaline Phosphatase (ALP) and the type I collagen (Coll-I) content. The gene expression of $A L P$, Coll-I, Osteocalcin $(O C), \operatorname{Runx} 2$, Osterix $(O S x)$, Osteoprotegerin $(O P G)$ and $R A N K L$ (receptor activator of NF-MB ligand) was observed using RT-PCR analysis.

Results: The results showed that CCPT treatment $(2.5,5.0$ and $10.0 \mathrm{mg} / \mathrm{ml})$ affected the proliferation of ROS1728 in a concentration-dependent manner. The highest expression was obtained by treatment with $5 \mathrm{mg} / \mathrm{ml}$ of CCPT after a nine-day treatment duration based on ALP activity and Coll-I content $(P<0.01)$ with the control group, whereas, the expression of ALP, Coll-I, OC, Runx2, Osx and OPG mRNA was facilitated $(P<0.01)$. Only the level of $R A N K L$ mRNA decreased compared with the control group $(\mathbf{P}<\mathbf{0 . 0 1})$.

Conclusion: Use of CCPT can induce ROS1728 proliferation into osteoblasts and enhance the function of osteogenesis through regulating the gene expression of Runx 2 and the osteogenesis-specific transcription factors of Osx, and inhibit bone absorption by OPG/RANKL/RANK signaling pathways.
\end{abstract}

Keywords: Colla Carapax et Plustrum Testudinis, ROS1728, Anti-osteoporosis, Molecular mechanisms. Accepted on November 20, 2017

\section{Introduction}

Osteoporosis, as one of the most common bone diseases, which is characterized by bone microstructure deterioration in addition to a reduction in bone mass, becomes a serious threat to post-menopausal women and elderly men [1,2]. As the number of elderly increases, the number of osteoporosis patients is expected to increase with an estimated patient population of 200 million worldwide [3]. Long-term use of western medical treatments for the effective prevention and control of osteoporosis is liable to result in a variety of side effects [4,5]. The development of Traditional Chinese Medicine (TCM) has attracted increasing attention, and many of its products have been recorded for use in the treatment of osteoporosis [6,7].

The decoction of colla Carapax et Plustrum Testudinis (CCPT), which was precious Traditional Chinese Medicine (TCM) and health food, has been recorded for thousands of years in China.
CCPT extracted from Carapax et Plustrum Testudinis according to the Chinese Pharmacopoeia [8]. Traditionally, it has been believed to nourish the kidney-yin and kidney-yang respectively, especially increase the sexual function in man [9]. Carapax et Plustrum Testudinis is rare and famous traditional animal-derived medicine, and is commonly administered to strengthen the bone in order to combat and treat osteoporosis. Theoretically, a concept in which the kidney governs the bones had been recorded for several thousands of years and it remains widespread in China. The deficiency in kidney function respectively is deemed to be closely related to osteoporosis as well as conditions of bones and joints [10].

There is no doubt regarding its therapeutic effect in enhancing bone and muscle strength, but its primary mechanism of action remains unclear, which limits its current application of them. Previous research has shown that collagen is the most abundant protein in Carapax et Plustrum Testudinis. Collagen is a protein in the bone tissue that plays an important role in bone 
metabolism [11]. According to traditional medicine theory, collagen can be used for preventing and control osteoporosis. Structurally, Carapax et Plustrum Testudinis's components are the same as human bone having a calcium phosphate matrix $(73 \%)$ and other organic materials (23\%). In organic materials, the collagens, which account for $80 \%$, are mainly a composition of fibrous tissues. However, the influence of the CCPT for managing osteoporosis remains unclear and has yet to be reported. This study was designed to investigate the effects of CCPT on the proliferation of ROS1728 cells. Our findings may provide theoretical evidence for the therapy of osteoporosis with CCPT.

\section{Materials and Methods}

\section{Reagents}

Dulbecco's Modified Eagle's Medium High Glucose (DMEMHG), Fetal Bovine Serum (FBS), trypsin and Dexamethasone (Dex) were purchased from Gibco (Grand Island, NY, USA). Rat collagen-I, protein assay kit and ELISA detection kit were obtained from the Jiancheng Bioengineering Institute (Nanjing China). TRIzol was purchased from Invitrogen (Carlsbad CA, USA). Primer synthesis and RT-PCR kit were purchased from Sangon Biotech (Shanghai, China). The CCK-8 kit reagents were purchased from Beyotime Biotechnology Institute (Haimen, China).

\section{Preparation and extraction of Colla Carapax et Plustrum Testudinis}

Raw materials of Carapax et Plustrum Testudinis were purchased from Beijing Tongrentang Pharmaceutical Co. Ltd., China. They were authenticated by an expert herbalist at Jilin Shenrong-ajiao Pharmaceutical Co. Ltd., China. CCPT was extracted from Carapax et Plustrum Testudinis via a trypsin hydrolysis method according to the previously reported protocol. Briefly, the materials $(0.5 \mathrm{~kg})$ were ground into small pieces $\left(2-3 \mathrm{~cm}^{2}\right)$ and washed with $75 \%$ alcohol to remove the dust and microorganisms within the surface. The pretreated sample of Carapax et Plustrum Testudinis was mixed with 0.1 $\mathrm{M} \mathrm{NaOH}$ at a ratio of 1:10 (w/v) for $24 \mathrm{~h}$. Afterwards, the sample was washed with the cold distilled water and put into the water at a ratio of 1:3-8 (w/v) $(\mathrm{pH} 7.5)$ and then trypsin was dissolved in the water at $1.0 \%$ concentration for enzymolysis for $2 \mathrm{~h}$ at $37^{\circ} \mathrm{C}$. At last, the mixture was boiled at $100^{\circ} \mathrm{C}$ for 30 min and centrifuged at $4000 \mathrm{rpm}$ for $20 \mathrm{~min}$, and the supernatant was freeze-dried. The powder of the water-soluble extract was collagen peptide. Based on the phytochemical experiment (Pharmacopeia of the People's Republic of China, 2015 edition), the contents of proteins were greater than $86 \%$ as calculated using Coll-I as standards. Before application, the CCPT powder was dissolved in deionized water at concentrations of $2.5,5$, and $10 \mathrm{mg} / \mathrm{ml}$.

\section{Preparation of ROS1728}

Rat Osteoblast cell line (ROS 1728) was purchased from the Cell Culture Center, Institute of Basic Medical Science,
Chinese Academy of Medical Science (Beijing, China). The harvest cells were centrifuged at $1500 \mathrm{rpm}$ for $5 \mathrm{~min}$ and then transferred into $25 \mathrm{~cm}^{2}$ culture flasks and cultured in an incubator at $37^{\circ} \mathrm{C}$ with $5 \% \mathrm{CO}_{2}$ and saturated atmospheric humidity in DMEM-HG complete medium, containing $20 \%$ FBS, $100 \mathrm{U} / \mathrm{ml}$ of penicillin, and $100 \mathrm{U} / \mathrm{ml}$ of streptomycin at $37^{\circ} \mathrm{C}$. The culture medium was changed on the second day and every two to three days thereafter. After waiting for cell growth at $80 \%$ to $90 \%$, a sub-culture was produced in the ratio of $1: 2$ $(\mathrm{V} / \mathrm{V})$.

\section{Analysis of CCPT molecular weight and amino acid}

Collagen peptide was analysed by the traditional amino acid method. Firstly, collagen was hydrolyzed under the accelerated testing vacuum in $6 \mathrm{~mol} / \mathrm{L} \mathrm{HCl}$ at $110^{\circ} \mathrm{C}$ for $24 \mathrm{~h}$. Secondly, amino acids were collected and converted to phenylisothiocyanate derivatives. At last, the molecular and amino acids contents were analysed by High Performance Liquid Chromatography (HPLC) (LC-20A; Shimadzu, Kyota, Japan) with Wondasil-C18 column $(4.6 \times 150 \mathrm{~nm}, 5 \mu \mathrm{m}$; Dikma, Beijing, China). The mobile phase was a mixture of $97 \%$ aqueous acetonitrile containing $0.1 \mathrm{~mol} / \mathrm{L}$ sodium acetate (eluent A) and $80 \%$ aqueous acetonirile (eluent B). The flow rate was set to $1.0 \mathrm{ml} / \mathrm{min}$ with a detection wavelength of 270 $\mathrm{nm}$ and the column temperature was $37^{\circ} \mathrm{C}$.

\section{ROS1728 proliferation assay}

ROS1728 proliferation was detected using cell counting kit-8 (CCK-8) according to the manufacturer's instructions. Briefly, ROS1728 cells were seeded into 96-well plates at a density of $2.5 \times 10^{4}$ cells $/ \mathrm{ml}$. The cultured cells were divided randomly into five groups: a normal control group, a Dex group (positive control), and low (extract-L, $2.5 \mathrm{mg} / \mathrm{ml}$ ), medium (extract-M, 5 $\mathrm{mg} / \mathrm{ml}$ ), and high (extract- $\mathrm{H}, 10 \mathrm{mg} / \mathrm{ml}$ ) treatment groups. In the Dex group, ROS1728 cells were cultured in medium containing Dex at $10^{-8} \mathrm{M}$. In a normal control group, cells were cultured in serum-free culture medium. The medium was changed for an equal volume of fresh medium every two days and supplemented with the drug at different concentrations. Next, $20 \mu \mathrm{L}$ of a $5 \mathrm{mg} / \mathrm{ml} \mathrm{CCK}-8$ were added to each well and the mixture incubated for $1 \mathrm{~h}$. The supernatant was collected on each of the first to the seventh day. The optical density (OD) was determined using an absorbance microplate reader (Bio Tek, Winoosski, VT, USA) at a wavelength of $450 \mathrm{~nm}$. Three independent repeats were done for all experiments.

\section{Osteogenic induction and measurement of the intracellular alkaline phosphatase (ALP) activity and Type I collagen (Coll-I) contents}

ROS1728 cells at passage two were seeded into 24 -well plastic plates in $1 \mathrm{ml}$ medium, at a density of $2.5 \times 10^{4}$ cells $/ \mathrm{ml}$. The cultured ROS1728 cells were divided randomly into three groups: a control group, a drug group, and a Dex group. Except for the Dex group, others were supplemented with osteogenic inducers, which consisted of $10 \mathrm{mM}$ beta glycerin sodium phosphate $(\beta-\mathrm{GP})$ and $50 \mu \mathrm{g} / \mathrm{ml}$ ascorbic acid. In the Dex 
group, ROS 1728 cells were cultured in medium plus, with Dex at $10^{-8} \mathrm{M}$. In the control group, cells were grown in medium with osteogenic inducers. In the drug group, cells were cultured with an additional drug dosage at different concentrations $(-2.5 \mathrm{mg} / \mathrm{ml}, 5 \mathrm{mg} / \mathrm{ml}$, and $10 \mathrm{mg} / \mathrm{ml})$ with osteogenic inducers. After three days, the culture medium was changed and supplemented with drugs according to group. The culture medium was changed every three days. Next, the supernatant was collected on the sixth, ninth and twelfth days, respectively; two markers of osteoblastic differentiation were evaluated. In brief, ALP activity was detected using an ALP reagent kit according to the manufacturer's instructions. The matrix was added to $100 \mathrm{ml}$ supernatant for $15 \mathrm{~min}$ at $37^{\circ} \mathrm{C}$, producing $1 \mathrm{mg}$ phenol as a Kim unit. The results were converted into international units $(1 \mathrm{Kim}$ unit is equivalent to 7.14 international units $\mathrm{u} / \mathrm{L}$ ).

The intracellular type I collagen was analysed using an ELISA Kit according to the manufacturer's instructions. Briefly, the supernatant was fixed with mice collagen I monoclonal antibody in a microtiter plate in advance and incubated with Biotin-labeled anti-collagen I antibodies and streptavidinlabeled Horseradish Peroxidase (HRP)-conjugated antibodies combined with an immune complex. At the end of incubation, the substrate was added, and the color development was quantified using a spectrophotometer (Bio Rad, Hercules, CA, USA) at a wavelength of $450 \mathrm{~nm}$. Based on the linear regression equation fitted to the standard curve, the corresponding sample concentration was calculated.

\section{$R \mathrm{NA}$ isolation and analysis of the mRNA expressions of ALP, Coll-I, OC, RunX2, OsX, OPG, and RANKL}

ROS 1728 cells at passage three were seeded into six-well plastic plates in $1 \mathrm{ml}$ medium, at a density of $2.5 \times 10^{4}$ cells $/ \mathrm{ml}$ and divided randomly into three groups as described in the ROS1728 proliferation assay protocol. The culture medium was changed every three days and the culturing the process was continued for nine days. The cell pellets were collected and total RNA was extracted with the TRIzol reagent. cDNA was synthesized with a cDNA Synthesis Kit according to the manufacturer's instructions. The relative amounts of each gene mRNA expression to G3PDH were measured by quantitative reverse transcripts PCR with the SYBR premixed system; the specific primer sequences for $A L P$, Coll-I, OC, RunX2, Osx, $O P G$ and $R A N K L$ are shown in Table 1. qRT-PCR was performed by using the appropriate kit. The relative transcript levels of the target gene were normalized to that of G3PDH using the $2^{-\Delta \Delta C t}$ assay.

Table 1. Oligonucleotide primer sequences used for identification of mRNA expression during ROS cells differentiation into osteoblasts. ALP: Alkaline Phosphatase; Coll-I: Type I Collagen; OC: Osteocalcin; OPG: Osteoprotegerin; Osx: Osterix; F: Forward, R: Reverse.

\begin{tabular}{lll}
\hline Primers & Sequence $\left(\mathbf{5}^{\prime}\right.$ to $\left.\mathbf{3}^{\prime}\right)$ & $\begin{array}{l}\text { Expected } \\
\text { length }\end{array}$ \\
\hline$A L P$ & F-AACGGGCCTAAGAACATCATCA & $126 \mathrm{bp}$ \\
\hline
\end{tabular}

\begin{tabular}{|c|c|c|}
\hline & R-TGTCCATCTCCAGCCGTGTC & \\
\hline \multirow[t]{2}{*}{ Coll-I } & F-CCTGG AAGAGATGGTGCT & $122 \mathrm{bp}$ \\
\hline & R-CCATTCTTGCCAGCAGGAC & \\
\hline \multirow[t]{2}{*}{$O C$} & F-ATGAGGACCСTCTCTCTGCTC & $292 \mathrm{bp}$ \\
\hline & R-GTGGTGCCATAG ATGCGCTTG & \\
\hline \multirow[t]{2}{*}{$O P G$} & F-CTCATCAGTTGGTGGGAATGAAGA & $106 \mathrm{bp}$ \\
\hline & R-ACCTGGCAGCTTTGCACAATTA & \\
\hline \multirow[t]{2}{*}{ RANKL } & F-CACCCAGCTGAAGATAGT & $180 \mathrm{bp}$ \\
\hline & R-CCAAGAATCTCCATACATGACG & \\
\hline \multirow[t]{2}{*}{ Runx2 } & F-CCAGATGGGACTGTGGTTACC & $380 \mathrm{bp}$ \\
\hline & R-ACTTGGTGCAGAGTTCA GGG & \\
\hline \multirow[t]{2}{*}{ Osx } & F- CAATGACTACCCACCСТTTCC & $248 \mathrm{bp}$ \\
\hline & R- TGCCCACCACCTAACC & \\
\hline \multirow[t]{2}{*}{ G3PDH } & F-TGAACGGGAAGCTCACTGG & $307 \mathrm{bp}$ \\
\hline & R-TCCACCACCCTGTTGCTGTA & \\
\hline
\end{tabular}

\section{Statistical analysis}

All groups were formed in duplicate. The datum was expressed as the mean $\pm \mathrm{SD}$, calculated from at least three independent experiments. Statistical comparisons were made using the twotailed Student's t-test. The analysis was performed using SPSS16.0 (USA) software package. Statistical significance was designated as $\mathrm{P}<0.05$.

\section{Results}

\section{Characterization of Colla Carapax et Plustrum Testudinis}

We used HPLC gel filtration chromatography to evaluate the molecular weight and amino acids contents of CCPT. The HPLC profile of the molecular mass of reference proteins was distributed in the range of $9.374-15.367 \mathrm{kDa}$. It demonstrated that the CCPT molecular weight was about the 9-15 kDa. Gly as the major amino acid was the most dominant amino acid, which accounts for $32.23 \%$. The CCPT also contained seven essential amino acids, which were made up of lysine, leucine, phenylalanine, threonine, valine, isoleucine and methionine.

\section{CCPT inhibits the proliferation of ROS1728 cells}

The effect of the CCPT on proliferation of ROS1728 cells was determined by CCCK assay. Following seven days of treatment with different concentrations of the CCPT, no significant cytotoxic effects were observed under microscopy (data not shown). Compared to the control group, treatment with 2.5 and $10 \mathrm{mg} / \mathrm{ml}$ significantly increased the OD values in a time dependent manner $(2.5 \mathrm{mg} / \mathrm{ml} \mathrm{P}<0.01,10 \mathrm{mg} / \mathrm{ml} \mathrm{P}<0.05)$. However, no significant difference was observed between treatment with $5 \mathrm{mg} / \mathrm{ml}$ and the control group $(\mathrm{P}>0.05)$, the effect at $5 \mathrm{mg} / \mathrm{ml}$ was similar to that in the Dex group. Besides, 
positive control with Dex also significantly increased the OD values compared with the media-only group $(\mathrm{P}<0.01)$ (Figure $1)$.

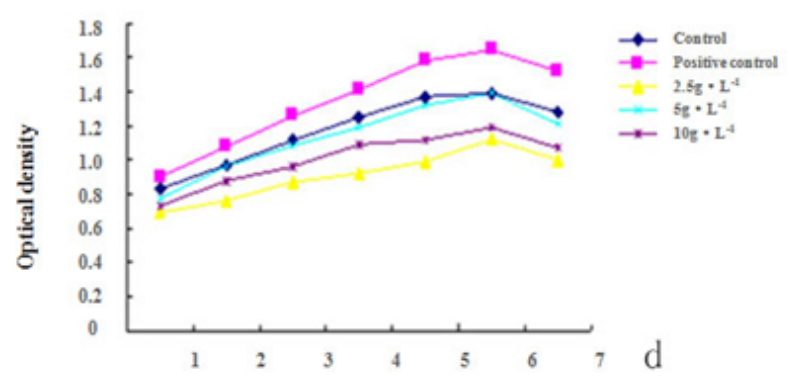

Figure 1. Assessment of the CCPT on proliferation of ROS1728 cells via the CCK-8 assay. CCPT: Colla Carapacis et Plastri Testudinis; CCK-8: Cell Counting Kit-8. The cultured cells were divided randomly into five groups: a normal control group, a Dex group (positive control), a low (extract- $L, 2.5 \mathrm{mg} / \mathrm{ml}$ ), a medium (extract- $M$, $5 \mathrm{mg} / \mathrm{ml}$ ), a high (extract- $\mathrm{H}, 10 \mathrm{mg} / \mathrm{ml}$ ) treatment group. Mean $\pm S D$ $(n=3)$; Compared to the normal control group, treatment with 2.5 and $10 \mathrm{mg} / \mathrm{ml}$ significantly increased the OD values in a time dependent manner $(2.5 \mathrm{mg} / \mathrm{ml} P<0.01,10 \mathrm{mg} / \mathrm{ml} P<0.05)$. However, no significant difference was observed between treatment with $5 \mathrm{mg} / \mathrm{ml}$ and the positive control group $(P>0.05)$. Besides, positive control with Dex also significantly increased the $O D$ values compared with the media-only group $(P>0.01)$.
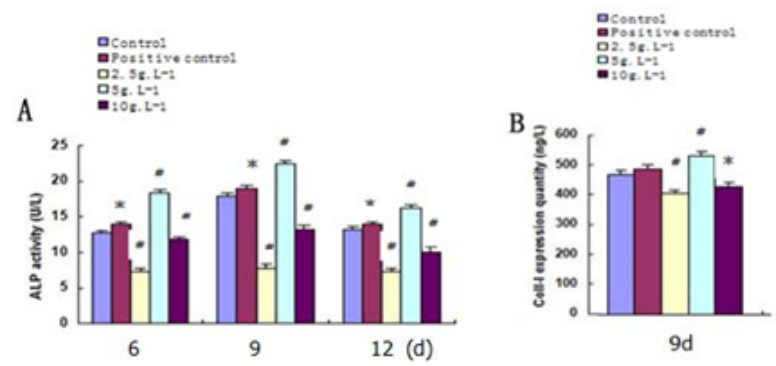

Figure 2. Measurement of the intracellular Alkaline Phosphatase (ALP) activity and type I collagen (Coll-I) contents during ROS1728 cells differentiation into osteoblasts. A: The effect of the CCPT on the ALP activity of the ROS1728 cells on the $6^{\text {th }}, 9^{\text {th }}$ and $12^{\text {th }} \mathrm{d}$. B: The effect of the CCPT on the expression of Coll-I in the ROS1728 cells on the $9^{\text {th }} d$. Mean $\pm S D ;{ }^{\#} P<0.05$, ${ }^{\#} P<0.01$ vs. the control group. ${ }^{\#} P<0.05$, ${ }^{\#} P<0.01 \mathrm{vs}$. the CCPT of $5 \mathrm{mg} / \mathrm{ml}$ group. ${ }^{*} P>0.05 \mathrm{vs}$. the CCPT of $10 \mathrm{mg} / \mathrm{ml}$.

\section{CCPT increased the alkaline phosphatase activity and Coll-I expression}

Following $12 \mathrm{~d}$ of treatment with different concentrations of the CCPT, intracellular ALP activities increased to their highest level on the ninth day among the drug groups. Compared with the control group, the activity was the lowest when treated with $2.5 \mathrm{mg} / \mathrm{ml}(\mathrm{P}<0.05)$, and the highest when treatment with $5 \mathrm{mg} / \mathrm{ml}(\mathrm{P}<0.05)$. However, no significant difference was observed between treatment with $10 \mathrm{mg} / \mathrm{ml}$ and control group $(\mathrm{P}>0.05)$, since the ALP activity for the 10 $\mathrm{mg} / \mathrm{ml}$ group was higher than the control group and $2.5 \mathrm{mg} / \mathrm{ml}$ group, lower than that for the $5 \mathrm{mg} / \mathrm{ml}$ group. Similarly, the intracellular Coll-I expression also increased highest on the ninth day among the drug groups. Compared with the control group, the content was the minimized during treatment with $2.5 \mathrm{mg} / \mathrm{ml}(\mathrm{P}<0.05)$, and the maximized during treatment with $5 \mathrm{mg} / \mathrm{ml}(\mathrm{P}<0.05)$. However, no significant difference was observed between treatment with $10 \mathrm{mg} / \mathrm{ml}$ and the control group $(\mathrm{P}>0.05)$, since the Coll-I expression for the $10 \mathrm{mg} / \mathrm{ml}$ group was higher than that of the control, and $2.5 \mathrm{mg} / \mathrm{ml}$, groups, but lower than that of the $5 \mathrm{mg} / \mathrm{ml}$ group (Figure 2).
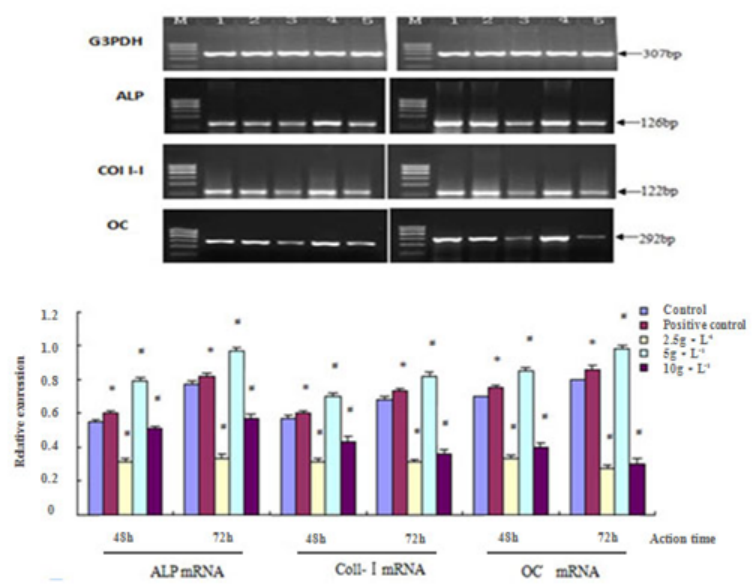

Figure 3. Effect of the CCPT on the gene expression of ALP, Coll-I and OC mRNA during ROS1728 cells differentiation into osteoblasts. Mean $\pm S D ;{ }^{\#} P<0.01$ vs. the control group. The temperature profile consisted of an initial denaturation step at $95^{\circ} \mathrm{C}$ for 5 min, followed by 30 cycles at $95^{\circ} \mathrm{C}$ for $30 \mathrm{~s}, 50 \sim 55^{\circ} \mathrm{C}$ for $30 \mathrm{~s}, 72^{\circ} \mathrm{C}$ for $30 \mathrm{~s}$ and final extension at $72^{\circ} \mathrm{C}$ for $5 \mathrm{~min}$.
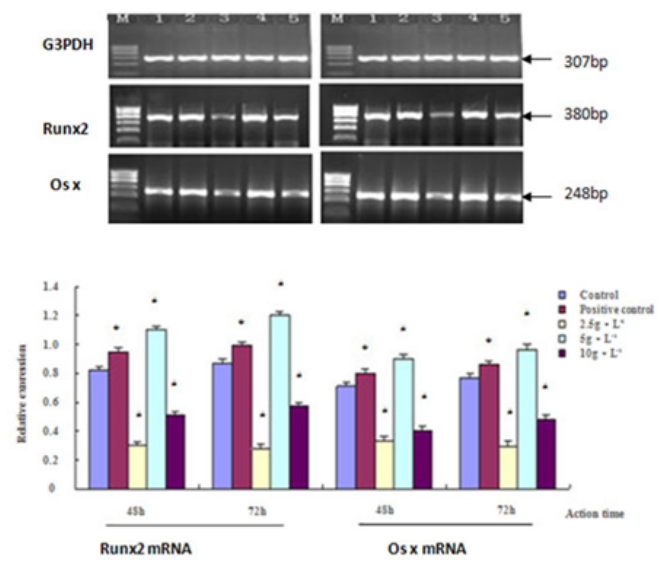

Figure 4. Effect of the CCPT on the gene expression of Runx2 and Osx mRNA during ROS1728 cells differentiation into osteoblasts. Mean $\pm S D ;{ }^{\#} P<0.01$ vs. the control group. The temperature profile consisted of an initial denaturation step at $95^{\circ} \mathrm{C}$ for 5 min, followed by 30 cycles at $95^{\circ} \mathrm{C}$ for $30 \mathrm{~s}, 55 \sim 57^{\circ} \mathrm{C}$ for $30 \mathrm{~s}, 72^{\circ} \mathrm{C}$ for $30 \mathrm{~s}$ and final extension at $72^{\circ} \mathrm{C}$ for $5 \mathrm{~min}$. 


\section{CCPT increased genes expression during ROS1728 cells differentiation into osteoblasts}

We measured the changes in ALP, Coll-I, OC, Runx 2, Osx, $O P G$ and $R A N K L$ mRNA to quantify possible CCPT-induced osteogenesis. The results showed that the band sizes of the gene expression were as expected with these primers. There were differences in gene expression quality among all groups. These effects were dose-dependent and indicated a similar pattern to the proliferation or differentiation. The maximum effect was achieved at $5 \mathrm{mg} / \mathrm{ml} \mathrm{CCPT} \mathrm{for} \mathrm{seven} \mathrm{genes} \mathrm{except}$ the $R A N K L$ gene, which resulted in a significant increase in mRNA levels compared with the control group $(\mathrm{P}<0.01)$. Conversely, only the level of $R A N K L$ mRNA decreased compared with the control group $(\mathrm{P}<0.01)$. Besides, mRNA expression of seven genes were restrained and reduced to approximately control group levels in $2.5 \mathrm{mg} / \mathrm{ml}$, and 10 $\mathrm{mg} / \mathrm{ml}$, groups (Figures 3-5).

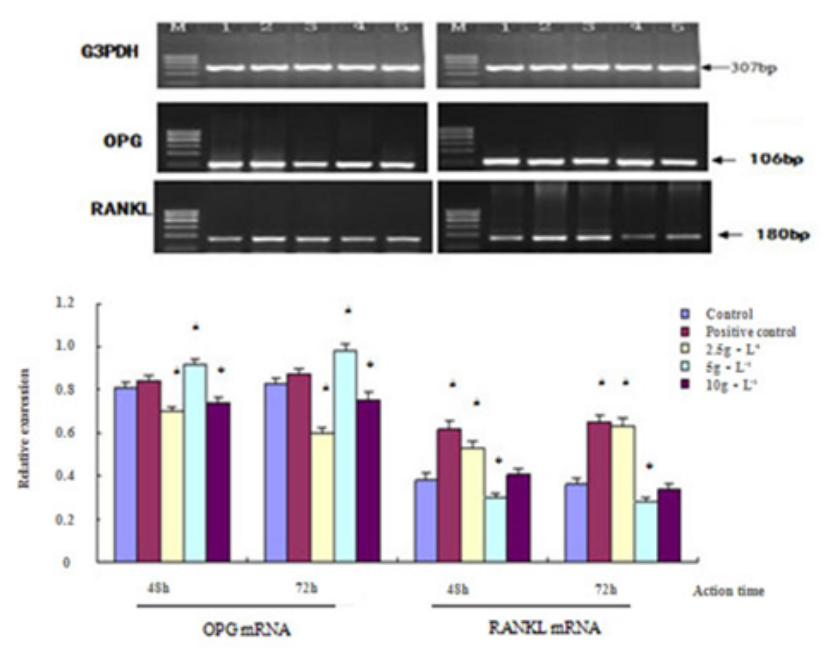

Figure 5. Effect of the CCPT on the gene expression of $O P G$ and RANKL mRNA during ROS1728 cells differentiation into osteoblasts. Mean $\pm S D ;{ }^{\#} P<0.01$ vs. the control group. The temperature profile consisted of an initial denaturation step at $95^{\circ} \mathrm{C}$ for $5 \mathrm{~min}$, followed by 30 cycles at $95^{\circ} \mathrm{C}$ for $30 \mathrm{~s}, 57 \sim 60^{\circ} \mathrm{C}$ for $30 \mathrm{~s}, 72^{\circ} \mathrm{C}$ for $30 \mathrm{~s}$ and final extension at $72^{\circ} \mathrm{C}$ for $5 \mathrm{~min}$.

\section{Discussion}

Normal bone metabolism is a dynamic balance of bone reconstruction, which includes osteoclast adherent to old bone areas, with secreting acid dissolved minerals and secretory proteinase digesting bone matrix, forming bone resorption lacunae. Followed by osteoblast cell migration were secreted bone matrix mineralization, and formation of new bone. The balance of bone resorption and bone formation is the key to maintaining normal bone mass. Osteoporosis is caused by an imbalance in remodelling along with decreasing bone formation and increasing bone resorption [12,13]. Increased numbers and production of osteoblasts is the key to overcoming this problem.

In this study, we report that the CCPT positively affect ROS1728 cells proliferation and osteogenic differentiation in a concentration dependent manner. Although the CCPT increased the proliferative capacity of ROS 1728 cells with the maximum effect at $5.0 \mathrm{mg} / \mathrm{ml}$, the positive effects were attenuated both at lower and higher concentrations of CCPT over time. In fact, the decoction composed of CCPT (as a kidney-Yang promoting herb) has been used to strengthen bones, develop muscles, and treat osteoporosis for several thousand years in Asia [14].

ALP and OC are biochemical markers of osteogenesis. The higher levels of ALP and Coll-I in the drug treatment group reflected the increase in bone formation. This suggested that the CCPT may help to prevent osteoporosis by decreasing osteoporotic bone metabolism. Coll-I is the major product of proliferating osteoblastic cells. The higher levels of Coll-I, which represent the formation and degradation marker, suggest "catching up" of the bone collagen matrix and normalization of bone metabolism [15]. Additionally, the mRNA of both ALP and Coll-I mark the formation of the organic matrix of bone and collagen synthesis, which are reported to be more sensitive than changes within cells. We measured the changes in ALP, Coll-I and OC mRNA expression. The results indicated that the expression levels of both ALP and Coll-I mRNA were concentration-dependent in response to different concentrations of CCPT. Both the low-dose, and high-dose, treatment groups decreased the mRNA expression of the three genes, and may have inhibited two types of osteoblast proliferation, also the function of the osteoblast, resulting in a decreased number of osteoblasts and decreased gene expression. The medium-dose treatment group increased the quantity, and expression, of the marker genes, despite the fact that it could not cause osteoblast proliferation, but could promote osteoblast function, and increase marker gene expression.

In this experiment, the medium-dose treatment group did not promote cell proliferation as expected from the results indicating cell function enhancement. Furthermore, the medium-dose treatment group can promote the mRNA expression of specific transcription factors Runx 2 and Osx in good agreement with the results from tests of gene expression of ALP, Coll-I and OC. It was speculated that the medium dose treatment group first promoted the gene expression of Runx2, which is key to adjusting osteogenetic differentiation, activating its downstream key factor gene $O s x$, and then promoting the gene expression of osteogenesis marker genes $A L P$, Coll-I and $O C$. Abundant collagen matrix generation forms new bone tissue through matrix mineralization. Osteoblast is buried in the bone matrix and into bone cells, promoting the formation of bone cells.

An osteoclast is a type of polynuclear giant cell, originating from hematopoietic stem cells, and belonging to the family of monocytes. Osteoclasts make contacting with the surface of bone mineralization areas and are activated; the activated osteoclasts can secrete hydrochloric acid and protease dissolved as an inorganic compound, absorbing and degrading organic matter. This is the process by which bone can permit the resorption of osteoclasts $[16,17]$. Osteoclast differentiation 
and maturation are affected by a variety of cells and cytokines, the receptor activator of the nf-kappa $\mathrm{B}$ ligand $(R A N K L)$, which is expressed in bone marrow stomatal cells or osteoblasts, is the key factor promoting osteoclast formation, differentiation; Osteoprotegerin (OPG) is a key molecule inhibiting osteoclast formation, and differentiation. This osteoclast precursor and its membrane surface can express the receptor activator of the nf-kappa $\mathrm{B}(R A N K)[18,19]$. Under physiological conditions, $R A N K L$ comes into contact with RANK, promoting osteoclast differentiation and function. Soluble OPG molecules as a decoy receptor, combine with $R A N K L$, allowing competitive blocking of the combination of $R A N K L$ and RANK, inhibiting osteoclast differentiation and maturation, inhibiting bone absorption, and increasing bone mass $[20,21]$.

The system of $O P G / R A N K L / R A N K$ plays an important role in maintaining the balance of bone resorption and normal bone formation [22]. Numerous studies have shown that the ratio of $O P G / R A N K L$ is a fundamental factor, which reduces osteoclast differentiation and allows for stable bone metabolism [23,24]. Our results show that the ССРТ(medium-dose treatment) could significantly promote the mRNA expression of OPG, but decrease the mRNA expression of $R A N K L$ and increase the ratio of OPG to $R A N K L$. OPG is prone to combining with $R A N K L$, resulting in a decrease in the amount of, and rate at which, RANKL combines with RANK in the osteoclast. While cell information cannot be conveyed within cells interior, the differentiation and maturation of osteoclasts are limited, and bone resorption will decline. The OPG/RANKL/RANK signaling pathway has become a key research topic in the study of osteoporosis [25]. The results show the action of CCPT can inhibit osteoclast differentiation, maturation, and inhibit bone absorption by OPG/RANKL/RANK signaling pathways. Further experiments will focus on its regulatory mechanisms.

This study suggested that the CCPT can induce ROS 1728 differentiation into osteoblasts, and can enhance osteogenesis, while regulating the gene expression of Runx 2 and Osx. The CCPT inhibits osteoclast differentiation, maturation, and bone absorption by OPG/RANKL/RANK signaling pathways. This experiment has practical significance with regard to expounding molecular mechanisms underpinning the pathogenesis thereof, and in finding an updated molecular target capable of preventing osteoporosis.

\section{Declaration of Interest}

The authors declare that they have no competing interests. The authors alone are responsible for the content and writing of the paper.

\section{Acknowledgments}

This study was a part of National Natural Science Foundation of China project (81402979), and received financial support from the Health Developing Program in Jilin Province, China (20112108); the Science and Technology Research Projects of the Department of Education of Jilin Province, China
(2011-132 and 2015151); the Jilin and Zhejiang Science and Technology Development Program (20140307008YY and 2014C33155).

\section{References}

1. Lodie TA, Blickarz CE, Devarakonda TJ, He C, Dash AB, Clarke J, Gleneck K, Shihabuddin L, Tubo R. Systematic analysis of reportedly distinct populations of multipotent bone marrow-derived stem cells reveals a lack of distinction. Tissue Eng 2002; 8: 739-751.

2. Meier C, Nguyen TV, Center JR, Seibel MJ, Eisman JA. Bone resorption and osteoporotic fractures in elderly men: the Dubbo osteoporosis epidemiology study. J Bone Miner Res 2005; 20: 579-587.

3. Center JR, Bliuc D, Nguyen ND, Nguyen TV, Eisman JA. Osteoporosis medication and reduced mortality risk in elderly women and men. J Clin Endocrinol Metab 2011; 96 : 1006-1014.

4. Szulc P, Montella A, Delmas PD. High bone turnover is associated with accelerated bone loss but not with increased fracture risk in men aged 50 and over: the prospective MINOS study. Ann Rheum Dis 2008; 67: 1249-1255.

5. Turgeon RD, Yeung SS. Fracture risk and zoledronic acid therapy in men with osteoporosis. N Engl J Med 2013; 368: 872-873.

6. Wu F, Li H, Jin L, Li X, Ma Y, You J, Li S, Xu Y. Deer antler base as a traditional Chinese medicine: a review of its traditional uses, chemistry and pharmacology. J Ethnopharmacol 2013; 145: 403-415.

7. Kaufman JM, Audran M, Bianchi G, Braga V, Diaz-Curiel M, Francis RM, Goemaere S, Josse R, Palacios S, Ringe JD, Felsenberg D, Boonen S. Efficacy and safety of strontium ranelate in the treatment of osteoporosis in men. $\mathrm{J}$ Clin Endocrinol Metab 2013; 98: 592-601.

8. Ch P. Chinese Pharmacopoeia 2010 edition. 2010; 168.

9. Kang SK, Kim KS, Kim SI, Chung KH, Lee IS, Kim CH. Immunosuppressive activity of deer antler extracts of Cervus korean TEMMINCK var. mantchuricus Swinhoe, on type II collagen-induced arthritis. In Vitro Cell Dev Biol Anim 2006; 42: 100-107.

10. Bauer DC, Garnero P, Harrison SL, Cauley JA, Eastell R, Ensrud KE, Orwoll E. Biochemical markers of bone turnover, hip bone loss, and fracture in older men: the MrOS study. J Bone Miner Res 2009; 24: 2032-2038.

11. Okazaki K, Sandell LJ. Extracellular matrix gene regulation. Clin Orthop 2004; 427: 123-128.

12. Charles P, Mosekilde L, Risteli L, Risteli J, Eriksen EF. Assessment of bone remodeling using biochemical indicators of type I collagen synthesis and degradation: relation to calcium kinetics. Bone Mineral 1994; 24: 81-94.

13. Canalis E, Economides AN, Gazzero E. Bone morphogenetic protein, their antagonists, and the skeleton. Endocr Rev 2003; 24: 218-235.

14. Kim HK, Kim JH, Abbas AA, Yoon TR. Alendronate enhances osteogenic differentiation of bone marrow 
stromal cells: a preliminary study. Clin Orthop Relat Res 2009; 467: 3121-3128.

15. Diekman S. No bones about a genetic switch for bone growth. Science 1997; 276: 1502.

16. Lee KS, Kim HJ, Li QL, Chi XZ, Ueta C, Komori T, Wozney JM, Kim EG, Choi JY, Ryoo HM, Bae SC. Runx2 is a common target of transforming growth factor $\beta 1$ and bone morphogenetic protein2, and cooperation between Runx2 and Smad5 induces osteoblast-specific gene expression in the pluri potent mesenchymal precursor cell line C2C12. Mol Cell Biol 2000; 20: 8783-8792.

17. Maeda S, Hayashi M, Komiya S, Imamura T, Miyazono K. Endogenous TGF- $\beta$ signaling suppersses maturation of osteoblastic mesenchymal cells. EMBO J 2003; 23: 552-563.

18. Kamakura S, Moriguchi T, Nishida E. Activation of the protein kinase ERK5/BMK1 by receptor tyrosine kinases. Identification and characterization of signaling pathway to the nucleus. Biol Chem 1999; 274: 26563-26571.

19. Li N, Zhang M, Drummen GP, Zhao Y, Tan YF, Luo S, Qu XB. Sika deer antler collagen type i-accelerated osteogenesis in bone marrow mesenchymal stem cells via the Smad pathway. Evid Based Complement Alternat Med 2016; 2109204.

20. Hassel S, Schmitt S, Hartung A, Roth M, Nohe A, Petersen N, Ehrlich M, Henis YI, Sebald W, Knaus P. Initiation of Smad-dependent and Smad-independent signaling via distinct BMP-receptor complexes. J Bone Joint Surg Am 2003; 3: 44-51.
21. Whitehurst A, Cobb MH, White MA. Stimulus-coupled spatial restriction of extracellular signal-regulated kinase $1 / 2$ activity contributes to the specificity of signal-response pathways. Mol Cell Biol 2004; 24: 10145-10150.

22. Sun P, Watanabe H, Takano K, Yokoyama T, Fujisawa J, Endo T. Sustained activation of M-Ras induced by nerve growth factor is essential for neuronal differentiation of PC12 cells. Genes Cells 2006; 11: 1097-1113.

23. Sharp CA, Magnusson P. Isoforms of bone alkaline phosphatase, stem cells, and osteoblast phenotypes. Stem Cells Dev 2008; 17: 857-858.

24. Hu Y, Chan E, Wang SX, Li B. Activation of p-38mitogenactivated protein kinase is required for osteoblast differentiation. Endocrinol 2003; 144: 2068-2074.

25. Li X, Cui Q, Kao C, Wang GJ, Balian G. Lovastatin inhibits adipogenic and stimulates osteogenic differentiation by suppressing PPAR gamma2 and increasing $\mathrm{Cbfal} / \mathrm{Runx} 2$ expression in bone marrow mesenchymal cell cultures. Bone 2003; 33: 652-659.

\section{*Correspondence to}

Mingcheng Li

Department of Clinical Diagnosis

School of Laboratory Medicine

Beihua University

PR China 